\title{
Transfer of Ownership Title under Albanian Company Law
}

\author{
Msc, PhD candidate ERJOLA ALIAJ \\ European University of Tirana \\ e-mail:aerjola@gmail.com
}

\begin{abstract}
Commercial activity is the one of the most important aspects of the market economy system. The exercise of commercial activity is regulated by legal rules, which serve as guaranteess for an adequate, reliable and effective mechanism of the commercial activity and also create a favorable business and incentives climate for the development of economic activities, which directly affects the country's economic growth. The freely transfer of ownership title over the shares is an important element, which guarantees the financial rights of the respective owners. Shares as ownership titles can be transferred under conditions specified in Albanian Company law. In practice, during its implementation, were identified ambiguities and several difficulties in relation to the procedure for the transfer of ownership titles over the shares. Precisely, through this paper is provided an analysis of the procedure and identified problems and the possibility to clarify or suggest any potential solutions.
\end{abstract}

Keywords: Albanian Company law, commercial company, transfer, shares.

\section{Introduction}

Shares or quotas of a legal entity and the rights deriving from them may be transferred through: purchase, inheritance and donation. ${ }^{1}$ Article 73 point 1 and article 117 point 1 of Company Law do not restrict the transfer of shares only through the above mentioned legal means but also include "any other manner provided by law". As a general rule, shares and quotas of a legal entity may be transfer freely, unless the statute of the company may restrict the transfer of shares, through the company approval or pre-emption right in the favor of the company or other partners. ${ }^{2}$ These statutory provisions should be compiled carefully, because the legal consequences are very different, depending on the company body, which is responsible for this approval, or the type and beneficiary of the pre-emption right (Malltezi, 2011). In general, the transfer of shares, which violate these special statutory conditions, even in case the buyers have acted in good faith, shall be considered null. Anyway, the statute may provide differently, for example, defining only the compensation of damages.

The rules for the transfer of quotas in the limited liability companies are different from the rules for the transfer of shares in joint stock companies.

\subsection{The transfer of quotas in the limited liability companies}

The partners may transfer the quotas to third parties with or without remuneration, as any other form of ownership which is recognized by law (Malltezi, 2011). As a general rule, each partner has only one quota. Based on article 75 point 1 of Company Law, despite the case when it is forbidden by the statute, quotas, subject of transfer, may be divided. Consequently, the partner has the right to sell even one part of his quota.

Limited Liability Company has a hybrid nature. The incorporation contract of this company is based on the personal acquaintance of the partners with each other, so it is a "intuitu persona" company (Dine, Blecher, Hoxha \& Race, 2008). Consequently, the participation of other persons in the company through the transfer of quotas may be restricted by statutory provisions. The restrictive provisions in the statute can be different: they can define a procedure for the control of

\footnotetext{
${ }^{1}$ Article 73 of Law No. 9901, dated 14.04.2009, "On Entrepreneurs and Companies".

2 Article 73 point 3 of Law No. 9901, dated 14.04.2009, "On Entrepreneurs and Companies".
} 
financial situation and third persons' integrity or define the execution of pre-emption right by the other partners. The statute should regulate the pre-emption right procedures: the time that the seller partner should give to the legal entity or the other partners to make a decision, the legal entity to be notified, the negotiations and their terms (Dine, Blecher, Hoxha \& Race, 2008).

Based on article 73 point 2 of Company Law, in case of transfer of shares by contract, the latter must be in written form. As a result, submission of the certificate that certifies the ownership of quota toward payment is not sufficient. On the other hand, the legalization by public notary does not constitute a binding condition (Bachner, Schuster \& Winner, 2009). Anyway, in the legal practice, partly due to the demands by NRC (National Register Center) and partly due to concerns in regard to the legal security, transfer of quotas agreements in a limited liability company still are legalized by a notary. The statute may contain other rules relating to the form, for example, mandatory legalization of signatures by a public notary. In this case, administrators can not sanction other formalities in the lack of such a statutory requirement (Malltezi, 2011). Until the recent amendments of company law, the legislator had not predicted the moment the quotas are considered transferred. The article 74 point 2 of Company Law has provided only that the registration of the transfer at NRC is declarative. As a result, the buyer of quota could be a partner without being registered, who can vote and is entitled to receive dividends. Whereas, third parties (for example: a second purchaser quota in question) may only rely on the registration performed at NRC. In absence of special provisions, have been applied the general rules of civil law (Bachner, Schuster \& Winner, 2009). Based on article 164 of Albanian Civil Code, the ownership acquired by the contract without any additional procedure. For this reason, the transfer of quotas must be executed when the contract brings consequences, which depend on the contractual clauses. In absence of any contractual clauses, the transfer of quotas can be executed at the moment when the contract is signed and from that moment the buyer may be considered a partner. It has created the problem for the notification of the company in relation to its partners. Of course, it creates a problem in regard to the company information about its partners. Legal entity law did not contain any specific provision in this regard (Dine, Blecher, Hoxha \& Race, 2008).

The last amendments of company law have regulated the above mentioned issues, providing that in case of quotas transfer through contract, the terms and the moment of ownership title transfer, including the payment date of the purchase price shall be defined in the contract. The contract for the transfer of quota should be in written form and the legalization by a public notary does not constitute a condition for the contract validity or registration. Unless otherwise provided by law or agreed by the parties, the validity for the transfer of ownership title shall not be conditioned by other formalities with declarative effect, including the registration formalities or publication of contract or transfer of ownership. ${ }^{1}$

Also, according to article 74 of company law, the person who transfer the quota and the person, who acquire it, are jointly liable toward the company for the obligations, deriving from the quota possession, from the moment of transfer until the moment of its registration at the National Registration Center (Malltezi, 2011). The jointly liability between the buyer and the seller for the obligations of quota arising from the possession of quota is a mechanism, which encourage the parties to make the registration of quota transfer at NRC. By the interpretation of this provision results that the joint liability exists only for the period between the signing of the contract and registration of transfer of quotas. (Dine, Blecher, Hoxha \& Race, 2008).

In this way, after the registration, only the person to whom is made the transfer as a new partner is responsible against the legal entity for the obligations associated with the partnership. (Bachner, Schuster \& Winner, 2009). This interpretation is not correct because the debtors, who have an outstanding contribution (previous partner), can be changed without the approval of the legal entity. Also this provision would be in contradiction with article 496 of the Civil Code, according to which the debtor replacement is possible only with the consent of the creditor. Consequently, for every liability arising prior to registration, the previous and new partners shall be jointly liable toward the company. The new partner shall be liable for all the obligations arising after the registration (Bachner, Schuster \& Winner, 2009).

\subsection{The transfer of shares in joint stock companies}

As mentioned above, the rules for the transfer of shares in joint stock company are different from the rules in limited liability companies for the fact that the legislator has abolished the preferential shares, which had priority under the previous legal

${ }^{1}$ Article 73 point 2 of the Law No. 9901, dated 14.04.2009, "On Entrepreneurs and Companies 
regime. According to company law, all the shares must be registered (Dine, Blecher, Hoxha \& Race, 2008). The title over the shares shall be transferred with the registration of the shares in the special stock register, which is held by the company. In other words, the company law does not contain any rule, regarding the format of the share purchase agreement, which is not mandatory to be in writing. In any case, the new shareholder must certify the transfer of shares, with the purpose to be registered as such in "the special register" of the shares kept by the legal entity (Malltezi, 2011). The legal entity may also allow the online registration. ${ }^{1}$ The ownership over the shares shall be transferred in the moment of registration at the special register kept by the company ${ }^{2}$. Although these articles only treat the presumption of the ownership of shares ${ }^{3}$ and the exercise of shareholders rights ${ }^{4}$, the intention of the legislator has been to relate the ownership share with the registration. For this reason, the legal entity as well as third parties might and should treat registered persons (in the register of the company) as shareholders. The presumption provided in article 119 paragraph 2 of company law is absolute and uncontested. Also, neither the registration in NRC nor the registration in the register of titles ${ }^{5}$ does not seem to play any role in this context. Unlikely to article 74 paragraph 1 of company law, there are no rules regarding the transfer of the existing obligations with the transfer of shares in joint stock companies. The article 113 of company law deals only with the repayment of the contribution before the registration of the company itself, whereas article 123 presupposes the obligation of a particular person and treats only the consequences of the delayed payment. The provisions of article 74 paragraph 1 of company law may also apply to joint stock companies, since there are no essential differences between these two types of companies that would bring to the necessity of a different treatment.

The special register of shares is held by the legal entity itself. 6 The responsibility of keeping the registry belongs to the administrators. ${ }^{7}$ In case that the administrator refuses to register the purchaser of shares, based on article 152 of company law, the buyer may require the court to execute the rights and the court shall order the administrators to register the new shareholder. The article 119 paragraph 3 of company law provides that the register of shares may be supervised not only by the shareholders, but also by the public. Hereby, the ownership of shares as a private matter returns to a public matter. In this situation, many European countries have either restricted the access to the registry only to the other shareholders, or defined specific reasons for supervising the register (Galgano, 2009).

The last amendments of company law have regulated the above mentioned issues, providing that in case of share transfer through contract, the terms and the moment of ownership title transfer, including the payment date of the purchase price shall be defined in the contract. The contract for the transfer of shares should be in written form and the legalization by a public notary does not constitute a condition for the contract validity or registration. Transactions in electronic format must be performed only in written form. Unless otherwise provided by law or agreed by the parties, the validity for the transfer of ownership title shall not be conditioned by other formalities with declarative effect, including the registration formalities or publication of contract or transfer of ownership. ${ }^{8}$

\subsubsection{The pre-emption right over the shares}

The law uses the term pre-emption right in order to identify the priorities of the existed shareholders to benefit from the transfer of existing shares or emission of new shares. (Galgano, 2009). Besides of the legal regulations, the statute of the company plays an important role for further regulation of this instrument. The law provides that the statute may impose filters to control the transfer of shares to third parties through statutory clauses, to require that any shareholder, who desires to sell its shares, must first offer them to the other shareholders of the company with terms not less favorable than those offered to third parties. In case the statute provides the pre-emption right for the transfer of shares from the existing shareholders, is important to be defined in the statute also the execution method of the pre-emption right. (Malltezi, 2011).

\footnotetext{
${ }^{1}$ Article 119 paragraph 3 of the Law No. 9901, dated 14.04.2009, "On Entrepreneurs and Companies".

${ }^{2}$ Article 117 point 2 and Article 119 point 2 of Law No. 9901, dated 14.04.2009, "On Entrepreneurs and Companies".

${ }^{3}$ Article 119 of the Law No. 9901, dated 14.04.2009, "On Entrepreneurs and Companies".

${ }^{4}$ Article 117 of the Law No. 9901, dated 14.04.2009, "On Entrepreneurs and Companies".

${ }^{5}$ Article 12 of the Law "On Securities", No. 9879, dated 21.2.2008

${ }^{6}$ Article 119 paragraph 1 of the Law No. 9901, dated 14.04.2009, "On Entrepreneurs and Companies".

${ }^{7}$ Article 119 paragraph 3 of the Law No. 9901, dated 14.04.2009, "On Entrepreneurs and Companies".

${ }^{8}$ Article 117 point 3 of the Law No. 9901, dated 14.04.2009, "On Entrepreneurs and Companies".
} 
Such a procedure should regulate the notification procedure of the company on behalf of the seller, the necessary information, the received offers by the third parties, the mute acceptance rule and the implementation method of the preemption right. The principle imposed by the law is that the company's shareholders have the pre-emption right of the recently issued shares of the company, in proportion with the registered capital parts, representing the shares owned by them (Dine, Blecher, Hoxha \& Race, 2008).

The pre-emption right might lose if shareholders do not exercise it within 20 days from the day of publication in the NRC of the decision to increase the registered capital of the company. With the transfer of the shares shall be transferred even the pre-emption right. The right of pre-emption of shares can be restricted or revoked through a decision of the General Assembly for the capital increase, according to a report issued by the administrators, which explain the reasons for taking such measures and calculation of the price of emission (Bachner, Schuster \& Winner, 2009).According to company law, such a restrictive decision can be obtained only if the restriction or exclusion from the rights has been previously published in the official website of the company and reported for registration in NRC. The law provides that a company share could be owned by one or more persons, who are jointly liable for the obligations deriving from the share ownership. In case the shareholders do not regulate their relationship, the provisions of civil code regarding co-ownership shall be applied (Bachner, Schuster \& Winner, 2009).

\section{Conclusions}

Quotas and shares represent ownership titles over parts of a commercial company capital. These ownership titles produce rights and obligations for the partners/shareholders of the commercial company. As to each ownership title, even in case of transfer of ownership over the quotas/shares, each party must comply with the rules of the contractual form. The contract for the transfer of shares/quotas must be in written form and the legalization by a public notary shall not constitute a condition for the contract validity or registration. The terms and the moment of ownership title transfer, including the payment date of the purchase price shall be defined in the contract. Also, the transactions in electronic format must be performed only in written form. The validity for the transfer of ownership title shall not be conditioned by other formalities with declarative effect, including the registration formalities or publication of contract or transfer of ownership. The numerous obligations on publication are not harmonized with each other and the publicity is excessive. The legal rules on the transfer of ownership title do not impose specific barriers, aiming to enhance the economic performance of the commercial company.

\section{References}

\section{Legislation}

[1] Law No. 9901, dated 14.04.2009, "On Entrepreneurs and Companies", as amended

\section{Monographies}

[2] Bachner, Th.,\& Schuster, E.,\&Winner, M. (february 2009). The new Albanian law "On companies" interpreted according to its sources in European law. Dudaj publications.

[3] Dine, J., \& Blecher, M., \& Hoxha, Sh., \& Race, B. (february 2008). The New Law on Entrepreneurs and Companies - commentary.

[4] Galgano, F. (2009). The commercial law. Entrepreneurs - commercial companies. Luarasi University Press.

[5] Malltezi, A. (2011). Albanian law of commercial companies. Mediaprint publishing house. 